Eastern Illinois University

The Keep

Masters Theses

Student Theses \& Publications

1995

\title{
Reproductive Success of Grassland Birds at East- Central Illinois Airports
}

Eric L. Kershner

This research is a product of the graduate program in Zoology at Eastern Illinois University. Find out more about the program.

\section{Recommended Citation}

Kershner, Eric L., "Reproductive Success of Grassland Birds at East-Central Illinois Airports" (1995). Masters Theses. 2024.

https://thekeep.eiu.edu/theses/2024

This is brought to you for free and open access by the Student Theses \& Publications at The Keep. It has been accepted for inclusion in Masters Theses

by an authorized administrator of The Keep. For more information, please contact tabruns@eiu.edu. 
THESIS REPRODUCTION CERTIFICATE

TO: Graduate Degree Candidates (who have written formal theses)

SUBJECT: Permission to Reproduce Theses

The University Library is receiving a number of requests from other institutions asking permission to reproduce dissertations for inclusion in their library holdings. Although no copyright laws are involved, we feel that professional courtesy demands that permission be obtained from the author before we allow theses to be copied.

PLEASE SIGN ONE OF THE FOLLOWING STATEMENTS:

Booth Library of Eastern Illinois University has my permission to lend my thesis to a reputable college or university for the purpose of copying it for inclusion in that institution's library or research holdings.

I respectfully request Booth Library of Eastern Illinois University not allow my thesis to be reproduced because: 


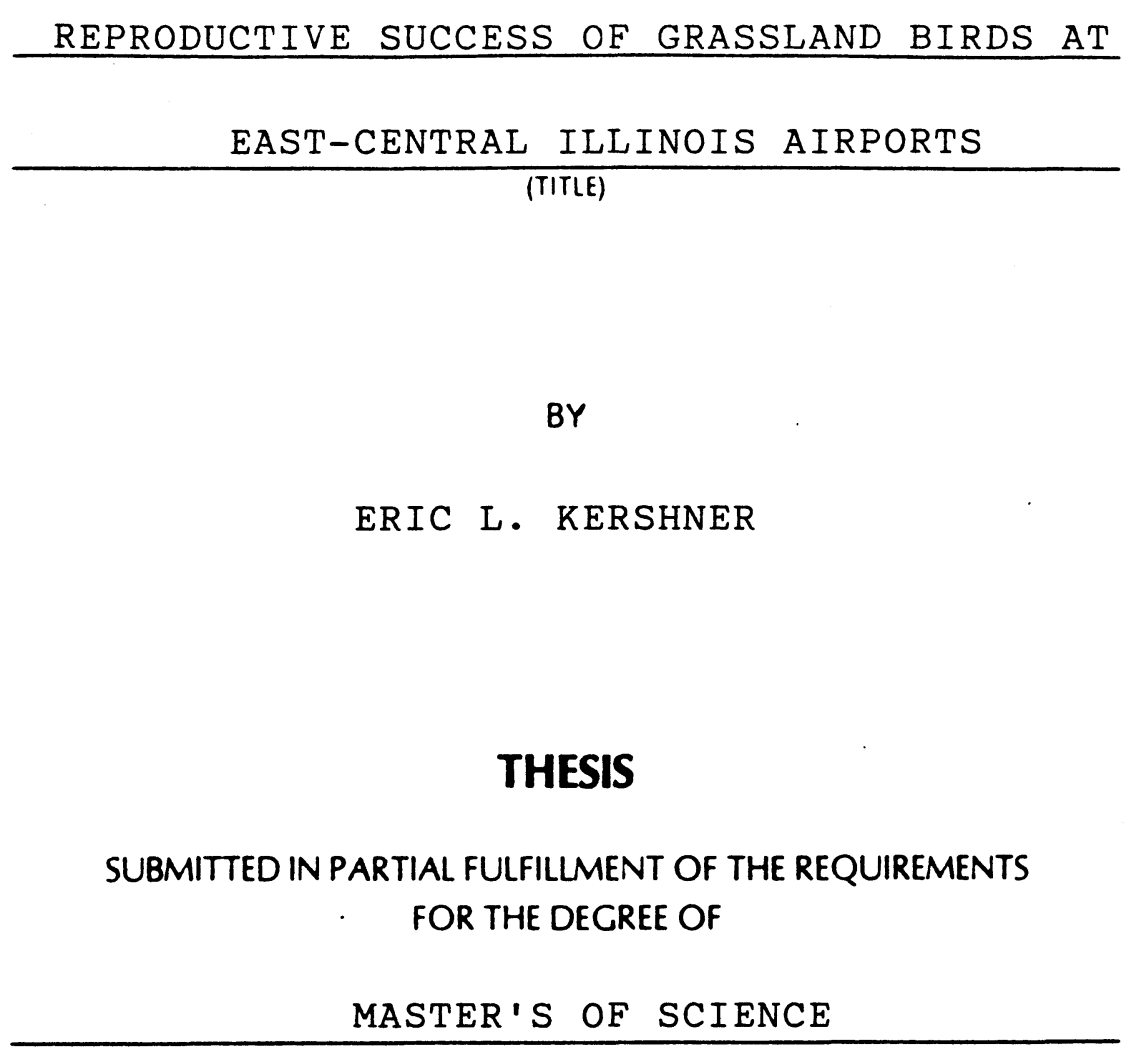

IN THE GRADUATE SCHOOL, EASTERN ILLINOIS UNIVERSITY CHARLESTON, ILLINOIS

1995

YEAR

I HEREBY RECOMMEND THIS THESIS BE ACCEPTED AS FULFILLINC THIS PART OF THE CRADUATE DEGREE CITED ABOVE

$29 J_{\text {une }} 1995$

30 June 1995 


\title{
REPRODUCTIVE SUCCESS OF GRASSLAND BIRDS
}

\section{AT EAST-CENTRAL ILLINOIS AIRPORTS}

\author{
By \\ Eric L.Kershner \\ Eastern Illinois University \\ Department of Zoology
}




\begin{abstract}
We determined the densities and reproductive success of birds on airport grasslands in east-central Illinois. Seven airports were sampled between 10 April and 15 August 1994 in Clark, Coles, Crawford, Douglas, Edgar, Macon and Richland counties. Nineteen species were detected on the airport grasslands and 147 nests were found representing six different species. Eastern meadowlarks (Sturnella magna) were the most abundant nesting species found; 105 out of the 147 nests $(71 \%)$. Other nesting species included: grasshopper sparrow (Ammodramus savannarum), savannah sparrow (Passerculus sandwichensis), red-winged blackbird (Agelaius phoeniceus), song sparrow (Melospiza melodia) and horned lark (Eremophilia alpestris). Overall nest success was $14 \%$, and ranged from $6 \%$ for red-winged blackbirds to $100 \%$ for horned larks. Individual airport nest success ranged from $0.02 \%$ at Robinson to $29 \%$ at Decatur. The overall nest density of 0.79 nests / ha is relatively low compared to other studies. However, eastern meadowlark nest density was 0.56 nests/ha, which is a relatively high value compared to other studies. Nearly all nest failure was attributed to mowing (44\% of all nests) or nest predation ( $23 \%$ of all nests) and mowing practices may indirectly increase nest predation rates. Management recommendations for these airports include mowing the grass lower and more often to discourage nesting by grassland birds, because grasslands associated with airports appear to be "ecological traps" for eastern meadowlarks and may be contributing to regional declines of other grassland bird species.
\end{abstract}




\section{ACKNOWLEDGEMENTS}

I would like to thank the College Faculty Research Grant and the Illinois State Academy of Science for the partial funding of this project. There are many people that I need to thank because without all of their help this effort would not have been accomplished. I thank Nancy Keyth for her dedicated assistance in the field collecting data. Doug Wood for the good friend that he is, the companionship that he gave during those long hours of birding and the critical ecological brainstorms that we shared. Dr. Michael Melampy for his advice and support and for reviewing the project proposal. Dr. Eric Bollinger for taking me on as a student, for constant patience, guidance and reassurance during the project, and for preparing me to continue on with future work. To Christine, Stephen, Mark and Kelly for their love and support, and an extra thanks to Mark and Kelly for their critical review of this manuscript. To Mom and Dad for their love and support, both financial and mental, for believing in me and allowing me to be an individual. Their patience is unmatched. To the person who probably suffered the most during this project, my wife Lisa. Thank you for not leaving me when I was hard to live with. Her love, support and patience was endless. 


\section{TABLE OF CONTENTS}

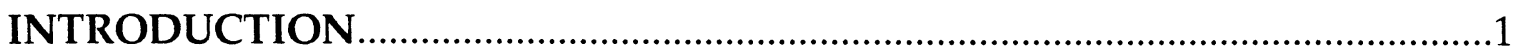

STUDY AREA

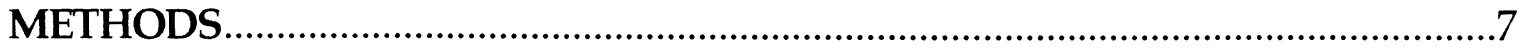

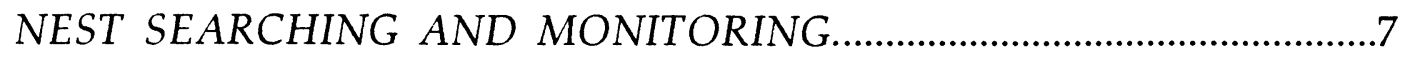

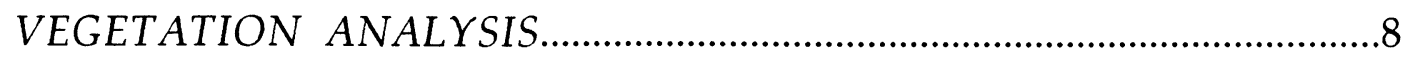

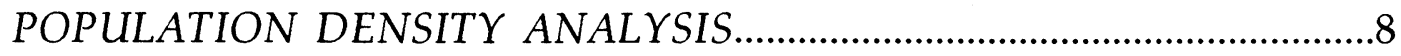

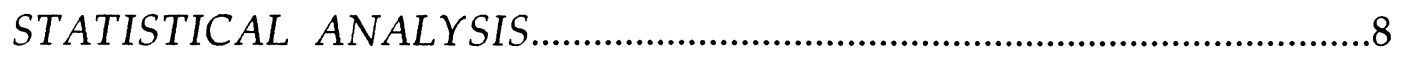

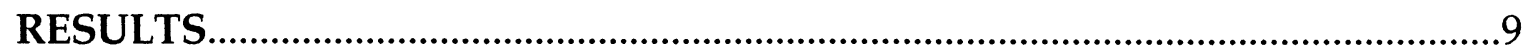

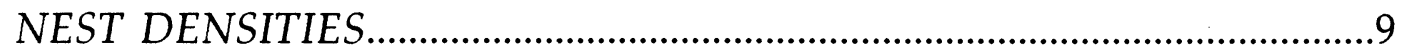

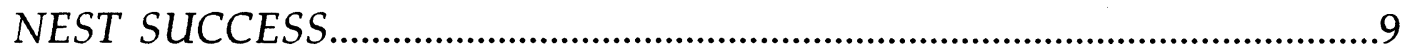

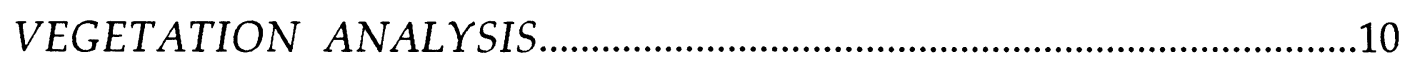

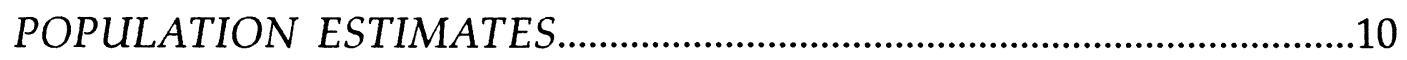

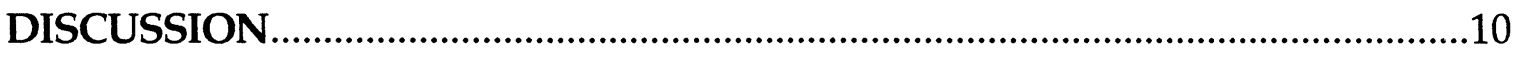

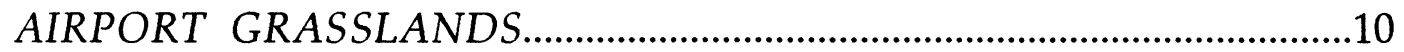

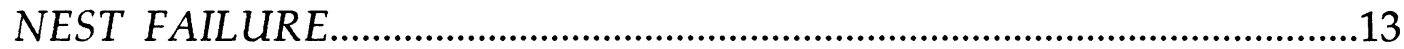

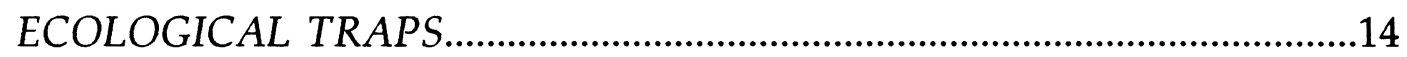

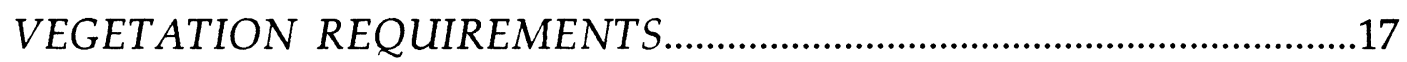

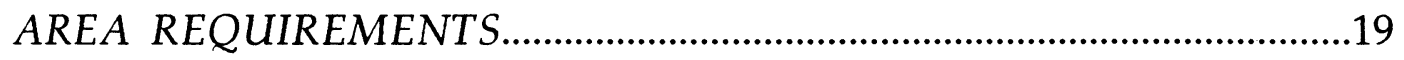

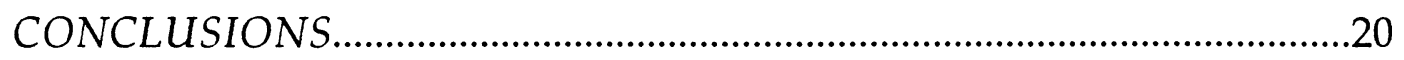

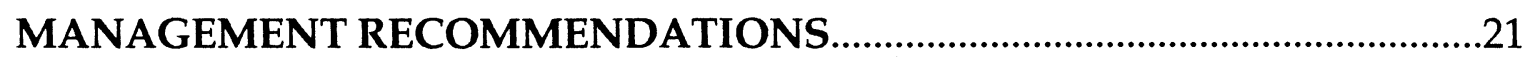

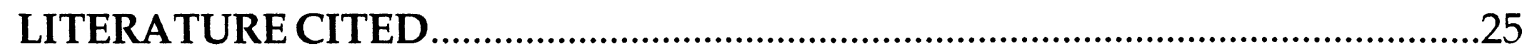

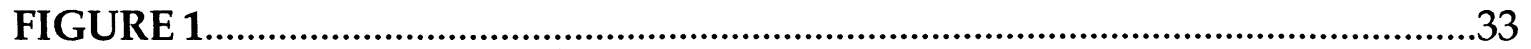

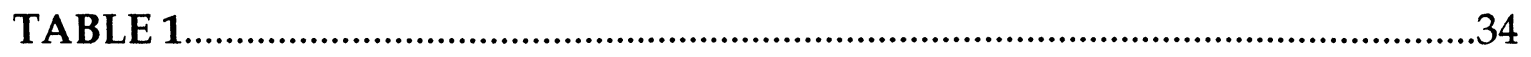

TABLE 2

TABLE 3

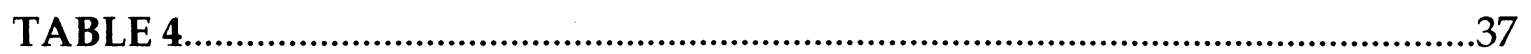


TABLE 5

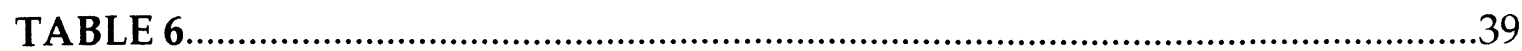

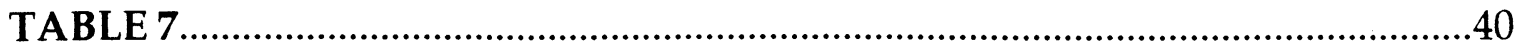

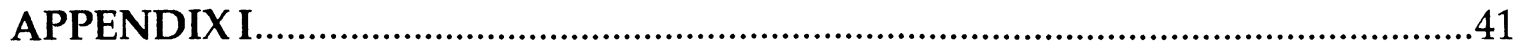

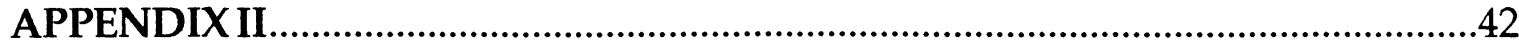




\section{INTRODUCTION}

There is compelling evidence that many grassland bird species are declining (Askins, 1993; Goriup, 1988). Over the past 25 years, grassland bird species have shown steeper, more consistent, and more geographically widespread population declines than any other behavioral or ecological group of species in North America (Herkert, 1994a; Senner, 1994). These declines involve species that share similar habitat and ecological requirements, indicating that there may be a few general causes for these declines, such as long term land conversion and intensive agricultural practices (e.g. mowing and hay cropping), which destroy breeding habitat (Askins, 1993; Bollinger, 1991). Conversion of grasslands to cropland has caused declines of grassland birds species in Argentina (Bucher and Nores, 1988), Brazil (Cavalcanti, 1988), England (Baines, 1988), India (Rahmani, 1988), the Netherlands (Beintema, 1988) and Spain (de Juana et al., 1988). Settlement of the Canadian prairies brought such profound changes in the region that some consider it the most devastating impact of humanity on any biome of the world (McNicholl, 1988). Before agriculture dominated the Midwest plains, tallgrass prairies characterized the landscape (Camp and Best, 1994). Agriculture and urban development have severely reduced and fragmented native grasslands throughout the Midwestern United States (Herkert, 1994a; Vance, 1976). Only relict tracts of prairie remain (Knopf, 1988), and these remnant tracts are usually small, isolated parcels surrounded by habitat unsuitable for most prairie birds (Birkenholz, 1973; Johnson and Temple, 1990).

Population declines appear to be more severe in Illinois than in any other "prairie" state. The tallgrass prairies that once covered Illinois have virtually disappeared; more than $99 \%$ of native grasslands have been lost 
(Herkert, 1991, 1994). The loss of native prairies and the present intensity of row-crop agriculture rank grassland habitat in Illinois among the most highly fragmented and endangered ecological systems in the eastern United States (Graber and Graber, 1963; Herkert, 1994a). Prior to European settlement, prairies occupied approximately 8.5 million hectares in Illinois (Herkert, 1991). However, by 1820 , prairie remnants of only 3,440 ha remained (Bowles et al., 1980; Hurley and Franks, 1976; Warner, 1992, 1994; Westemeier and Buhnerkempe, 1983). During this time, bird declines were widespread and severe. Between 1900 and 1950, relatively few changes occurred in grassland bird populations (Warner, 1994). During this time, small patchwork farms in Illinois produced a diversity of commerciai products (Warner, 1994). However, at the start of the 1950s, large farms planting primarily row crops replaced the small, more diversified farms (Camp and Best, 1994). This intensification of row crops occurred as synthetic fertilizers and mechanical and chemical cropping practices became widespread (Warner, 1994). Corn and soybean farming has expanded from 4.9 million ha in 1945 to about 8.4 million ha during the 1980s (Warner, 1992), and Illinois has among the largest proportions of any state dedicated to corn production (Best et al., 1990).

As row cropping has intensified, grassland birds have typically declined by up to $85-90 \%$ (Herkert, 1991). By 1978, there were only 1,089 designated natural areas in Illinois, representing only $0.7 \%$ of the land area (Mankin and Warner, 1992). Fewer than $20 \%$ of the state's 245 native prairie remnants are greater than 10 ha and only nine are greater than 40 ha (Herkert, 1994a).

An important consequence of this habitat fragmentation is the loss of individuals and small populations (Herkert, 1991). Thirteen of the 26 grassland bird species known to breed in Illinois (Graber and Graber, 1963) 
have populations that are significantly declining nationally and/or regionally (Herkert, 1994a), including: eastern meadowlarks (Sturnella magna), dickcissels (Spiza americana), grasshopper sparrows (Ammodramus savannarum), bobolinks (Dolichonyx oryzivorus), lark sparrows (Chondestes grammacus) and some are considered threatened or endangered in the state, including: Henslow's sparrows (Ammodramus henslowii) and upland sandpipers (Bartramia longicauda) (Bohlen, 1989; Bowles et al., 1980; Graber and Graber, 1963; Herkert, 1991, 1992, 1994; Senner, 1994 - see Appendix II). Illinois has extirpated three prairie species (the sharp-tailed grouse [Pediocetes phasianellusl whooping crane [Grus americana] and the swallow-tailed kite [Elanoides forticatus]), and a fourth species, the greater prairie chicken (Tympanuchus cupido) was on the verge of extinction before recent translocations (Bowles et al., 1980; Herkert, 1991).

Of the species that are showing significant population declines, the Henslow's sparrow may be on the verge of extinction. Once abundant in Illinois, Henslow's sparrows are now considered a local summer resident in northern and central Illinois counties (Bowles et al., 1980; Herkert, 1994b). Grasshopper sparrows tend to be a specialist species, most likely to be found nesting in large fragments. They tend to disappear from any site that has undergone habitat changes including fragmentation (Askins, 1993; Herkert, 1994a). Overall, grasshopper sparrows and Henslow's sparrows have declined by nearly $70 \%$ in the United States over the last 25 years (Herkert, 1994a, 1994b). Upland sandpipers have also undergone severe declines in Illinois. Populations declined from an estimated 283,000 in 1909 to 177,000 in 1958 (Graber and Graber, 1963). Eastern meadowlarks also have shown population declines, although not as severe as other grassland species. Illinois 
populations decreased slightly from 4,760,000 in 1909 to 3,800,000 in 1958 (Graber and Graber, 1963).

Grassland avifauna have persisted locally at relatively high densities on "substitute prairies," such as pastures and hayfields (Birkenholz, 1973; Westemeier and Buhnerkempe, 1983). However, the land devoted to substitute grasslands is generally of lower quality for nesting than native grasslands due to high levels of disturbance (e.g., mowing and grazing) and exotic vegetation (Bollinger, 1991). Furthermore, these secondary habitats are on the decline as well (Herkert, 1994a). Between 1960 and 1995, the land devoted to hay crops in Illinois declined by more than half $(850,000$ to 450,000 ). Since 1906, pasture area has declined by greater than $75 \%$ (Herkert, 1991).

High densities of nesting birds have also been found in linear grassland habitats such as roadsides and fencerows in agricultural regions (Bryan and Best, 1994). Unfortunately, small linear habitats often do not sustain birds that require interior habitats (Warner, 1994). Airports often contain linear grassland habitats. Where native grasslands have been nearly eliminated, as in Illinois, airports provide some of the largest remaining open grasslands available to nesting grassland species. Beck (1942) noted that because the East had been settled, the last remaining continuously open, flat grasslands are at airports. He noted that these areas became ideal breeding grounds for upland sandpipers. Airports and military runways in Massachusetts and Connecticut have some of the largest remaining populations of upland sandpipers, grasshopper sparrows, savannah sparrows, horned larks and vesper sparrows (Crossman, 1989; Vickery et al., 1994). Upland sandpipers have been noted to choose airports over all other habitats for nesting in Ohio and on Long Island 
(Andrle and Carroll, 1988; Osborne and Peterson, 1984). Thus, airports appear to be critical refuges for many species of grassland birds. However, frequent disturbances (e.g. mowing) at airports may offset these conservation benefits.

The purpose of this study was to determine the use of airports by grassland birds in an intensive agricultural region of Illinois. Furthermore, we wished to determine the productivity of grassland birds on airport grasslands. The primary objectives of the study were:

1. To determine population and nest densities of grassland birds at airports.

2. To determine the reproductive success of grassland birds at airports.

3. To determine the impact that mowing practices have on grassland bird productivity.

4. To devise management strategies that will enhance the productivity of grassland birds in agricultural regions.

\section{STUDY AREA}

The study was conducted at seven airports in East-central Illinois in Clark, Coles, Crawford, Douglas, Edgar, Macon and Richland counties (see Fig. 1). These were small-to medium-sized airports, typically surrounded by corn and soybean fields. Each airport had a somewhat unique management regime; sections within airports that were managed differently were treated separately throughout the study.

CASEY AIRPORT - This airport was classified as a Basic Utility I airport (IIl. Dept. Trans., 1985). There were 10 ha of grassland suitable for nesting. This airport was separated into two sections (Casey 1 and Casey 2). Casey 1 was a 2 ha plot that was not mowed during this study. Casey 2 consisted of 8 
ha of grassland that were mowed nine times between 10 April and 15 August. Grass was mowed to $5.1 \mathrm{~cm}$.

COLES AIRPORT - Classified as a General Transport airport (Ill. Dept. Trans., 1985), there were 33 ha of grassland that were separated into two sections (Coles 1 and Coles 2). Coles 1 was a small 3 ha plot that was mowed once during the breeding season to a height of $21 \mathrm{~cm}$. Coles 2 consisted of the remaining 30 ha and was mowed eleven times to a height of $15 \mathrm{~cm}$.

DECATUR AIRPORT - The largest airport used as a study site was classified as an Air Carrier (IIl. Dept. Trans., 1985). There were 160 ha of grass area on this airport, but only 12 ha were studied due to F.A.A. safety regulations. The study section was mowed less frequently (nine times) than the rest of the airport. The grass in this section was allowed to grow to taller heights $(7.6 \mathrm{~cm})$ than the rest of the airport.

OLNEY AIRPORT - This General Utility airport (Ill. Dept. Trans., 1985) had 68 ha of grassland separated into two sections (Olney 1 and Olney 2). Olney 1 was a 24 ha area adjacent to runways and taxiways. This area was mowed 14 times to a height of $3.8 \mathrm{~cm}$. Olney 2 was 44 ha and was only mowed once during the field season to a height of $25.4 \mathrm{~cm}$.

PARIS AIRPORT - This Basic Transport airport (Ill. Dept. Trans., 1985) had 17 ha of grassland. Mowing heights were set at $10.2 \mathrm{~cm}$; the entire airport was mowed nine times during the breeding season.

ROBINSON AIRPORT - One of the largest airports used, this Basic Transport airport (IIl. Dept. Trans., 1985) had 44 ha of grassland. This grassland was mowed 12 times to a height of $6.4 \mathrm{~cm}$ during the field season.

TUSCOLA AIRPORT - This small airport was classified as a Residential airport (Ill. Dept. Trans., 1985). There were only 3 ha of grassland. This 
airport was mowed quite often (16 times) throughout the breeding season. Mowing height was set at $3.8 \mathrm{~cm}$.

\section{METHODS}

Nest searching and Monitoring - Nest searches began 10 April and continued through 15 August 1994. Each airport was searched at least once a week and usually twice if time permitted. Nests were located primarily by using the rope drag method (Higgins et al., 1969). Two people walked $\sim 60 \mathrm{~m}$ apart while dragging a $1.27 \mathrm{~cm}$ diameter rope between them, flushing incubating birds off their nests. Nests were also located by incidental flushing and by following adults that were feeding nestlings. Nests were marked by placing flagging tape on the nearest runway light or some other conspicuous object. Compass bearings and exact measurements were recorded from the nest flag to the nest. Nests were visited one to two times per week until the nest fate was determined.

Reproductive success was determined using the Mayfield method (Mayfield, 1961; 1975). A nest was considered active if there was at least one egg present in the nest. Nests that were found with either crushed eggs or dead nestlings were categorized as destroyed by mowing. A nest was categorized as abandoned if on three successive visits there was no activity at the nest and eggs were cold. A nest was considered destroyed due to predation when all contents of an active nest were removed or when a nest was found in a disturbed state when mowing had not recently taken place.

Nest densities (nests/ha) were calculated for each airport. A minimum density was estimated in an attempt to reduce the positive bias in measuring the densities due to frequent renesting. Estimates of this minimum density 
were derived by charting all nests from start to finish and estimating the minimum number of nests active at one time. The maximum density was simply the total number of nests found at each airport divided by the airport area.

Vegetation analysis - Two vegetation analyses were conducted at each airport. The first was a percent cover analysis, i.e., a visual estimation of the percent vegetation cover in five, randomly-located, $5 \mathrm{~m} \times 5 \mathrm{~m}$ plots on each airport section. These data allowed me to determine the dominant vegetation types on each airport section. The second vegetation analysis was a survey at meadowlark nests. Eighteen meadowlark nests were randomly selected (but evenly distributed across all airport sections), for vegetation analysis. We used a $0.25 \mathrm{~m}^{2}$ circular plot to estimate the percent vegetation cover around each nest. For comparison, vegetation was also surveyed in plots randomly located, but $35 \mathrm{~m}$ away from each surveyed nest.

Population density - Population density estimates of breeding birds were made using the line transect method (Anderson et al., 1979; Emlen, 1971, 1977; Jarvinen and Vaisanen, 1975). Airports were censused twice between 6 June to 19 June 1994. Transect lengths were determined by using the longest runway at each airport; transect widths remained constant at $50 \mathrm{~m}$ on each side of the transect line. Right angle distances from the transect line to the bird were estimated, and densities were derived using the DISTANCE software program (Burnham et al., 1980; Laake et al., 1994). Statistical analysis - Spearman Rank correlations (Sokal and Rohlf, 1981) were used to compare the relationship between all habitat parameters [nest density, nest success, mowing height, mowing frequency, $\%$ grass cover, $\%$ clover cover and \% other forb cover (all forbs other than clover)]. Paired $t$ - 
tests were used to compare the meadowlark nest sites with the random sites.

\section{RESULTS}

Nest Densities - A total of 147 nests was found on the 10 airport sections. Eastern meadowlarks were the most common nesting species, comprising $71 \%$ of all nests located. Other species found nesting included grasshopper sparrows, savannah sparrows, red-winged blackbirds, song sparrows and horned larks (Table 1). Overall, nest density was 0.79 nests/ha for all airports combined. Airport nest density ranged from 0.0 nests/ ha at Tuscola to 5.0 nests / ha at Coles 1 (Table 2). Nest densities ranged from 0.02 nests/ha for song sparrows and horned larks, 0.06 nests/ha for grasshopper sparrows, savannah sparrows and red-winged blackbirds to 0.56 nests/ha for eastern meadowlarks.

Nest density tended to decline as mowing height decreased $\left(r_{S}=0.510\right.$, $\mathrm{P}<0.1)$ and mowing frequency increased $\left(\mathrm{r}_{\mathrm{S}}=-0.659, \mathrm{P}<0.025\right)$. Other habitat parameters were not significantly correlated with nest density (Table 3). Nest Success - Of the 147 nests found, only 118 were used to calculate nest success because the nest chronology for 29 nests could not be determined. Nest success for all species combined was $14 \%$ and ranged from $6 \%$ for redwinged blackbirds to $100 \%$ for horned larks (Table 1). Eastern meadowlark nest success was $14 \%$. Nest success at individual airports ranged from $0.02 \%$ at Robinson airport to $29 \%$ at Decatur airport (Table 2).

As mowing frequency and $\%$ grass cover increased, nest success decreased $\left(r_{S}=-0.570, P<0.1\right.$ and $r_{S}=-0.778, P<0.01$, respectively $)$. Nest success also increased as $\%$ clover cover $\left(\mathrm{r}_{\mathrm{S}}=0.544, \mathrm{P}<0.1\right)$ and $\%$ non-clover forb cover 
$\left(\mathrm{r}_{\mathrm{S}}=0.820, \mathrm{P}<0.01\right)$ increased (Table 3$)$.

Vegetation Analysis - The results from the vegetation survey varied for each of the airport sections. The predominant cover type at all airports was grass. The percent area covered by grass ranged from virtually 100\% (Tuscola and Olney 1) to $61.2 \%$ (Decatur) (Table 2). The next most abundant cover type was clover (Table 2). The percent bare ground was low across all airport sections (Table 2).

Vegetation analysis at meadowlark nests showed that nest sites were dominated by grass cover (83.5\%) with lesser amounts of forb cover $(11 \%)$ and clover cover (5.4\%) (Table 6). There was no bare ground present at meadowlark nest sites compared with $4.2 \%$ bare ground at non-nest sites (paired $\mathrm{t}=-2.05, \mathrm{df}=17, \mathrm{P}<0.1$ ). Within the grass category, the percentages of live grass and dead grass were differentiated (Table 6). There was somewhat less live grass found at nest sites compared to random sites (paired $\mathrm{t}=-2.04, \mathrm{df}=$ $17, \mathrm{P}<0.1$ ), and a higher percentage of dead grass at nest sites (paired $\mathrm{t}=2.58$, $\mathrm{df}=17, \mathrm{P}<0.05)$.

Population estimates - Population densities were calculated for the three most common grassland species found on airport grounds (eastern meadowlarks, grasshopper sparrows and savannah sparrows). Eastern meadowlark densities ranged from 0.49 birds/ ha to 1.65 birds/ ha, grasshopper sparrow densities ranged from 0.0 birds/ ha to 2.83 birds/ha and savannah sparrow densities ranged from 0.0 birds/ha to 4.35 birds/ha (Table 7).

\section{DISCUSSION}

Airport grasslands - Many anthropogenic grassland habitats have been created and have helped to slow or stop grassland bird declines. These areas 
may be critical refuges for grassland bird populations. These secondary grasslands consist mainly of pastures and hayfields within agricultural regions. Hayfields, appear be viable habitats for species such as the bobolink. Bollinger et al. (1990) estimated that $74 \%$ of the bobolink population in their New York study area nested in hayfields. Linear habitats such as roadsides (Warner, 1992) and grass waterways (Bryan and Best, 1991) have also become important habitats for grassland birds. Reclaimed surface-mines have created large tracts of grassland for potential use by grassland birds, especially for grassland sparrows (Whitmore, 1981; Wray et al., 1982).

Airports generally contain large areas of anthropogenic grassland habitat. In this study, we documented a variety of different groups of birds utilizing these habitats (see Appendix I for complete list of all species detected). For example, some species seemed to use airport grasslands mainly as foraging sites, but tended to nest elsewhere. These included the common grackle (Quiscalus quiscula), European starling (Sturnus vulgaris), house sparrow (Passer domesticus), killdeer (Charadrius vociferus), American robin (Turdus migratorius), common flicker (Colaptes auratus), American woodcock (Philohela minor) and American crow (Corvus brachyrhynchos). During spring migration, some species were detected using airport grasslands as resting and foraging sites. This group consisted mainly of migrating shorebirds, including lesser golden plovers (Pluvialis dominica), semipalmated plovers (Charadrius semipalmatus), greater yellowlegs (Tringa melanoleuca), solitary sandpipers (Tringa solitaria), pectoral sandpipers (Calidris melanotos) and several "peep" sandpipers (Calidris spp.). Locally rare species were also observed on airport grounds during the study. Upland sandpipers were observed on three of the seven airports studied, but we 
found no evidence that they bred successfully on airport grasslands. We believe that this species may have been nesting in adjacent habitats and using the airports as separate foraging sites (Buss and Hawkins, 1939).

Although there is ample evidence that grassland birds utilize airport grasslands, there appears to be little evidence that these habitats will reverse or slow grassland bird population declines. Low nest success in grassland fragments is a main factor causing population declines and the loss of some species (Burger et al., 1994). The low nest success in this study suggests that airport grasslands have low productivity for grassland birds. The overall nest success for the six species found nesting on ten airport grasslands was $14 \%$. Breeding success is typically low among grassland birds (Ricklefs, 1969); however, our results are much lower than typical breeding success, which ranges between 25-55\% (Vickery et al., 1992b). When comparing studies that looked specifically at eastern meadowlarks (Table 5), nest success on airport grasslands (14\%) was significantly lower than the nest success found for hayfields (25.7\%), fallow fields (29.6\%) and pastures (42.9\%) (Roseberry and Klimstra, 1970).

Size of the grassland habitat may be an important factor influencing nest success for grassland bird species (Bollinger et al., 1990; Herkert, 1994a). However, there was no evidence of a size relationship in this study (Table 3). The highest nest success (29\%) was on an intermediate-sized airport section, whereas the two largest airport sections had nest successes of $25 \%$ and .02\% (Table 2). The smallest airport section (Casey 1) had the fourth highest nest success $(11 \%)$. This relatively high nest success may be attributed to the fact that this airport section was only mowed once during the breeding season, which created an undisturbed section of grassland. Other sections that were 
considered relatively undisturbed were Coles 2 with a success of $7 \%$ and Olney 2, which had the second highest nest success (25\%) (Table 2). When nest success was correlated to mowing frequency, the main cause of disturbance, the correlation was marginally significant, indicating that the fewer times an airport is mowed, the more successful grassland birds tended to be. Therefore, the productivity of a particular grassland may be directly related to the level of disturbance it receives and to a lesser extent to the size of the grassland habitat.

Nest Failure - Forty-four percent of all nests were destroyed by mowing, the primary cause of nest failure in this study. Bryan and Best (1994) found that $16 \%$ of nest mortalities were caused by mowing in grassed waterways, the second highest cause for nest failure in that habitat. Losses to mowing in many different grassland habitats were high among eggs (12\%), but seemed to have little impact on young (Roseberry and Klimstra, 1970). Mowing reduced potential fledgling production in bobolinks by $29-45 \%$ in high-quality agricultural areas, but only 6-8\% in low-quality agricultural areas (Bollinger et al., 1990). Bollinger et al. (1990) also reported that the timing of mowing was critical to bobolink production. If mowing occurred two weeks later in the season, bobolinks suffered only 7-8\% mortality. If mowing occurred two weeks earlier in the season, they suffered $32-44 \%$ mortality. It appears that early nesters are less affected by mowing than late nesters (Beintema, 1988) and that continuous mowing may cause some species to abandon the habitat for the entire season (Frawley and Best, 1991).

Nest predation was the second highest $(23 \%)$ cause of nest failure in our airport grasslands. This is not consistent with other studies of linear grassland habitats, which show that nest predation is the primary cause for 
nest failure (Bryan and Best, 1994; Camp and Best, 1994; Ricklefs, 1969; Rodenhouse and Best, 1983; Vickery et al., 1992b; Wray et al., 1982). Greater nest predation might be expected in linear habitats because predators may use these habitats as travel lanes (Bryan and Best, 1994). In addition, nest predation rates may also be area-related. Prairie fragments less than 15 ha have been shown to have higher predation rates than fragments greater than 30 ha (Burger et al., 1994).

The primary nest predators on airport grasslands were probably snakes such as prairie king snakes (Lampropeltis calligaster calligaster) and garter snakes (Thamnophis spp.). Most nests that were depredated showed little sign of disturbance, a good indicator of snake predation (Camp and Best, 1994). Other nests were found with the nest linings torn out and egg fragments present at the nest site, characteristic of mammalian predators (Camp and Best, 1994). Mowing may be indirectly related to nest predation rates for mammalian predators. Most species nesting on these airports were open-cup nesters, which usually build a dome structure above the nest to help conceal it from predators. As mowing occurred, if the nest was not destroyed, dome structures were mowed away making the newly exposed nests presumably easier for predators to locate.

Ecological Traps - The low level of nesting success on airport grasslands indicated that these habitats are unproductive compared with most other grassland habitats. In fact, airports form sink populations (Pulliam, 1988), in which reproduction is clearly below replacement levels for most species (Best, 1986). Two important factors regulating replacement levels are the number of young fledged per year and juvenile mortality (Sullivan, 1989). Adult survival for small passerines is estimated to be $\sim 50 \%$, whereas fledgling 
survival to the first breeding season is estimated to be between 15 and $30 \%$ (Ricklefs, 1969; Rodenhouse and Best, 1983; Wray et al., 1982). Therefore, to offset $50 \%$ adult mortality, annual productivity must be between 3.3 and 6.7 fledglings per pair (Rodenhouse and Best, 1983; Wray et al., 1982). Grassland birds nesting on our airport study sites were producing less than one fledgling per pair, which is well below replacement levels.

Sinks depend on immigration from source populations in higher quality habitats (Pulliam, 1988; Wray et al., 1982). In source populations, where reproductive productivity exceeds mortality, a large number of juveniles will emigrate into sink habitats (Howe et al., 1991; Pulliam, 1988; Van Horne, 1983). When breeding adults are territorial and favorable habitat is limited, a surplus of subdominant breeders may accumulate in sinks where either no breeding takes place or breeding attempts are largely unsuccessful (Van Horne, 1983; Pulliam, 1988 ). Wray et al. (1982) documented four sparrow species that continued to attempt to breed in sub-optimal habitat due to site tenacity and the availability of attractive nest sites. This behavior tends to elicit a settling response, but this response is apparently insufficient to insure adequate reproductive success in the sink habitats (Wray et al., 1982). By leaving the more productive source habitat when the local population exceeds the number of breeding sites available, an individual may increase its own fitness and ultimately the fitness of the entire population (Pulliam, 1988). Philopatry and nest replacement may influence the continued existence of sink populations. Philopatric species generally continue to return to sub-optimal habitat to breed, with little or no success.

There is a strong possibility that airport grasslands are "ecological traps," at least for eastern meadowlarks. Ecological traps are man-made areas 
that, on the basis of physical and/or vegetational characteristics, appear to be suitable habitats for nesting but because of confounding factors, result in population sinks rather than sources (Best, 1986). At airports, the confounding factors are primarily mowing practices. Airports probably appear attractive to grassland birds because of the lack of traditional breeding habitat left. Henriksen (1991) noted that the ringed plover's (Charadrius hiaticula) traditional breeding habitat has been lost, which has led to dispersal into other habitats where the reproductive rate is too low to maintain the population. To show that these habitats are attractive to grassland species, we must look at the rates of recruitment into these sink populations. Recruitment may be the key to keeping these populations in existence. Species in a fixed area of habitat usually exist in an equilibrium between mortality and recruitment (Beintema, 1988). Recruitment can be enhanced by either increasing the clutch size, reducing egg losses in any given breeding season, increasing the number of clutches per season or increasing immigration into the population (Beintema, 1988). These strategies do not appear to be suitable for airport grasslands. Mowing can easily offset these recruitment strategies, and it appears that it has. Philopatry may affect recruitment rates, emigration and population growth (Crossman, 1989). With recruitment low within airport populations, the habitat must appear attractive to birds emigrating out of source populations or coming from other sink populations.

Nest density may be used to determine whether airport grasslands are attracting more birds than other, more productive habitats. The nest density for airport grasslands was calculated to be 0.79 nests/ha. When compared to four other studies of similar habitats that combined all nesting species (Table 
4), all of the other studies had a higher nest density than airport grasslands. The highest nest density (2.93 nests/ha) was found on roadways (Warner, 1992). Other habitats that surpassed airports in nest density were grassed waterways (2.4 nests/ha) (Bryan and Best, 1994), many combined linear habitats (2.2 nests/ha) (Warner, 1994) and sandplain grasslands (1.6 nests/ha) (Vickery et al., 1992b).

Eastern meadowlarks were by far the most common bird nesting on airport grasslands, with a nest density of 0.56 nests/ha. When compared with studies that looked specifically at eastern meadowlarks, only one of six studies (on idle grasslands, Skinner, 1975) had a higher nest density than airport grasslands (Table 5). Nest density may be a reflection of the amount of disturbance that takes place between these two habitats. Idle grasslands probably have few disturbances compared to the rigorous airport maintenance schedule (especially mowing), which may discourage birds from nesting in this habitat once mowing has begun. Eastern meadowlark nest density was higher on airport grasslands than on roadsides ( 0.29 nests/ha) (Camp and Best, 1994), a prairie chicken sanctuary (0.07 nests/ha) (Westemeier and Buhnerkempe, 1983), fallow grasslands (0.05 nests/ha), hayfields (0.31 nests/ha) and pastures (0.52 nests/ha) (Roseberry and Klimstra, 1970). It is interesting to note that pastures and airport grasslands had nearly identical nest densities for eastern meadowlarks. However, meadowlarks on airports had a nest success of $14 \%$ compared to $43 \%$ on pastures (Table 5), suggesting that airports are ecological traps for eastern meadowlarks because they have relatively high nest densities but low productivity (see also Bryan and Best, 1994; Vickery et al., 1992a).

Vegetation Requirements - Vegetation structure may be a better way to 
determine how attractive a habitat appears to any given species, as nest density may not be a consistent indicator of habitat quality (Askins, 1993; Van Horne, 1983; Vickery et al., 1992a). The selection of the proper vegetation structure for nesting is often directly related to reproductive output (Buhnerkempe, 1979). If we examine the vegetation requirements for the three most abundant species found on airport sections (eastern meadowlarks, grasshopper sparrows and savannah sparrows), we can estimate how suitable these airport grasslands appear to be for these species.

Eastern meadowlarks are most frequently found in habitats that have a high percentage of grass cover and a low percentage of bare ground (Askins, 1993; Buhnerkempe, 1979). All but two airport sections (Decatur and Olney 2) had a percentage of grass cover over $80 \%$ and all airport sections had low percentages of bare ground (Table 2). The typical vegetation height for meadowlark habitat is estimated between 28.2 and $37.8 \mathrm{~cm}$ (Buhnerkempe, 1979; Roseberry and Klimstra, 1970). This is higher than the vegetation heights of all of the airport sections, which ranged from $3.8 \mathrm{~cm}$ to $25.4 \mathrm{~cm}$. This may indicate that meadowlarks may not require all habitat characteristics to be present before they utilize a given site. If enough of the characteristics are present, they can adapt to the shortcomings of one vegetational characteristic, in this case the vegetation height. Askins (1993) noted that another requirement for meadowlarks is the presence of thick layers of dead grass. This is also consistent with the vegetational surveys on meadowlark nests in this study. The percentage of dead grass found at meadowlark nest sites (33\%) was significantly different from the percentage of dead grass found at non-nesting sites.

Grasshopper sparrows were the most specialized species (Vickery et al., 
1992a) found nesting on airport sections. Typically, grasshopper sparrow habitats consist of $25 \%$ grass cover, $5-25 \%$ forb cover, $22-36 \%$ bare ground, and an average vegetation height of $43.2 \mathrm{~cm}$ (Delany et al., 1985; Whitmore, 1979, 1981). Grasshopper sparrows are expected to use areas with high availability of bunch grasses (Askins, 1993). This appears to be somewhat consistent with our study. The airport that contained the highest density of grasshopper sparrows was Paris, which had a relatively high percentage of forb cover compared to the other airports (Table 2). Furthermore, Paris had the highest percentage of bare ground out of all airport sections $(3 \%)$ even though this value was much lower than the values reported from other grasshopper sparrow nesting habitats.

Savannah sparrows have been characterized as generalists that prefer high amounts of continuous grass cover and lower amounts of forb cover (Askins, 1993; Wiens, 1974). Paris was the site with the greatest concentration of savannah sparrows. This site had intermediate grass cover, but also had a higher percentage of forb cover which is probably not an optimal habitat for this species. Savannah sparrows have been documented as more likely to nest in poorer quality habitats than other grassland species (Vickery et al., 1992a), and this may be the case for the sparrows nesting on airport grasslands. The possibility exists that the vegetation cover types in these sink habitats are not the optimum habitats, but the best remaining habitats available (Skinner, 1975).

Area Requirements - Another factor that may influence habitat choice by grassland birds is the habitat size. Grassland area had a significant positive influence on the probability of occurrence of eastern meadowlarks, grasshopper sparrows, savannah sparrows, bobolinks and Henslow's sparrows 
within grassland fragments in Illinois (Herkert, 1994a, 1994b; Vickery et al., 1994). Herkert (1994) estimated the minimum area requirements for these five species to be 5 ha for eastern meadowlarks, 30 ha for grasshopper sparrows, 40 ha for savannah sparrows, 50 ha for bobolinks, and 55 ha for Henslow's sparrows. In our study, eastern meadowlarks were found nesting on all airport sections which is what you would expect from looking at Herkert's (1994) minimum area requirements. However, Herkert's (1994a, 1994b) data seem inconsistent with the size of airport sections where we found grasshopper and savannah sparrows nesting. Grasshopper and savannah sparrows were most common on the Paris airport (17 ha) and savannah sparrows were also found nesting on an airport section of 8 ha, much smaller than the minimum required area suggested by Herkert (1994a). Although bobolinks were not found nesting and were only encountered on a few occasions, this is probably due to the fact that some of the airports were too far south for breeding bobolinks. Henslow's sparrows were not encountered at all during the study. This result reinforces Herkert's (1994a, 1994b) conclusion, that large areas of grassland are required for these species to breed successfully and small fragments might not be as productive as large fragments. Bobolinks and Henslow's sparrows also need the tallest vegetation which, are rare on airport grasslands (Herkert, 1994a, 1994b). Conclusions - It has been suggested that airports may be critical refuges for breeding grassland birds and under proper management these habitats may slow or stop grassland bird population declines. During this study we found that many grassland bird species are utilizing airport grasslands as nesting sites, and based on nest densities, it appears that airport grasslands are especially attractive for eastern meadowlarks. Meadowlarks may be attracted 
to these habitats because airport vegetation characteristics are closest to those required for optimal productivity. However, during the breeding season, airport mowing practices lowered the productivity of nesting birds well below replacement levels, forming population sinks. It appears that airport grasslands may, in fact, be ecological traps for eastern meadowlarks.

\section{MANAGEMENT RECOMMENDATIONS}

To conserve the genetic diversity of native prairie flora and fauna, the acquisition and proper management of grassland resources must become a priority (Ryan, 1986). One factor that may assist in maintaining populations of grassland birds is their rapid colonization of isolated areas of suitable habitat (Askins, 1993). However, many complications arise with the acquisition of new grasslands. Many of these newly formed or acquired grasslands may have become overrun by exotic vegetation. Although most native species of grassland wildlife readily accept and sometimes thrive on exotic vegetation, it seems that the reestablishment and maintenance of native vegetation should be emphasized (Westemeier and Buhnerkempe, 1983). Due to specialization, not all grassland birds utilize the same habitats within native grasslands. Therefore, in order to support a high diversity of species, a mosaic of habitat types within each grassland must be preserved (Renken and Dinsmore, 1987; Ryan, 1986).

While large areas of grassland could easily be managed for a patchwork mosaic, this would not be an effective approach in small grasslands (Askins, 1993). Evidence has shown that large diverse blocks will contain more species (Herkert, 1994a; Ryan, 1986), and enhance nest success in grassland habitats (Johnson and Temple, 1990; Vickery et al., 1994). 
However, we should not ignore secondary grasslands that currently support grassland bird populations as we conserve new large grasslands. Many existing grasslands are artificial habitats that grassland birds have adapted to. They consist of roadsides, waterways, pastures, hayfields, and other agricultural fields. Many grassland species are using these habitats. We should try to assist these species in achieving successful populations until better-suited habitats can be preserved. Secondary habitats may have significant conservation values even though they are incapable of supporting viable populations by themselves (Howe et al., 1991). Therefore, conserving buffer habitats and marginal sub-populations may help the entire population in the short term until better management strategies can be developed. The best way to aid grassland bird populations in these habitats is to reduce the amount of disturbance during the breeding season. Human disturbances, consisting of machinery operations that do considerable damage to nests, should be reduced to a minimum during critical stages of the breeding season (Bryan and Best, 1994; Graul, 1980; Herkert, 1994a). Mowing is the most common form of this type of disturbance. Ironically, mowing is considered a wildlife management tool (Bollinger et al., 1990; Bryan and Best, 1994; Camp and Best, 1994; Frawley and Best, 1991; Kirsch et al., 1978; Ryan, 1986; Skinner, 1975), but annual mowing often does not accommodate the needs of nesting grassland birds (Frawley and Best, 1991). Some studies suggest that mowing should be delayed until after the 1st of August to provide safe nesting periods (Bryan and Best, 1991, 1994; Buhnerkempe and Westemeier, 1988; Camp and Best, 1994; Warner, 1992). However, delayed mowing often may not be practical because of conflicts with modern forage management practices (Frawley and Best, 1991). Therefore, a solution must be reached by either 
changing forage management practices or developing new management strategies to preserve bird populations in these habitats.

Airports can also serve as an artificial habitat for nesting grassland birds. However, airports represent a challenge in proposing management recommendations. It has been suggested that if airport habitats are adequately managed, they may play an important role in producing stable breeding densities of grassland birds (Askins, 1993; Osborne and Peterson, 1984; Vickery et al., 1994). Askins (1993) suggested that since airports are mowed regularly, the mowing schedule should be adjusted to prevent nest destruction and to maintain a diversity of vegetation types. I agree that would be an optimal management plan, but realistic only for large airports. The Federal Aviation Association (F.A.A.) has regulations for the vegetation characteristics of each airport (Ill. Dept. Trans., 1985). F.A.A. vegetation regulations state that vegetation can not be high enough to obscure vision of any airport structures such as runway lights (approximately $0.75 \mathrm{~m}$ ) or signs. F.A.A. regulations also stipulate that vegetation should not reach heights that create "wildlife habitat". Airports also are required to maintain what is known as the "Runway Safety Area". This area must be kept in a condition that emergency or maintenance vehicles can travel with relative ease alongside runways and taxiways. This area is roughly 150 to 300 meters, depending on the classification of airport, extending out from the center line of each runway or taxiway on both sides.

Therefore, for small rural airports surrounded by agriculture, we feel that the most productive management plan may be to discourage grassland birds from attempting to nest. By discouraging birds from nesting in these habitats, it would encourage them to find new, possibly better habitats that 
might lead to greater productivity (Wray et al., 1982). To discourage nesting at these airports, it would be necessary to mow the vegetation lower and more frequently. At the Tuscola airport, the mowing height was $3.8 \mathrm{~cm}$ and no birds were found nesting there. It appeared that there was not enough cover for birds to attempt to nest. The Olney airport (section 1) was also mowed to $3.8 \mathrm{~cm}$, and only four nests were found in this section throughout the breeding season. This management recommendation may seem extreme, but it does not make sense to recommend that small airports, that must comply with F.A.A. regulations, attempt to enhance breeding grassland birds. If the area of an airport is large enough to comply with F.A.A. vegetation regulations and also contain areas that could be set aside for wildlife management, then the first strategy could become important for the maintenance of grassland bird populations. 


\section{LITERATURE CITED}

Anderson, D.R., J.L. Laake, B.R. Crain and K.P. Burnham. 1979. Guidelines for line transect sampling of biological populations. J. Wildl. Manage. 43: 70-78.

Andrle, R.F. and J.H. Carroll. 1988. The atlas of breeding birds in New York state. Cornell University Press, Ithaca, N.Y.

Askins, R.A. 1993. Population trends in grassland, shrubland and forest birds in Eastern North America. Current Ornith. 11: 1-34.

Baines, D. 1988. The effects of improvement of upland, marginal grasslands on the distribution and density of breeding wading birds in Northern England. Biol. Conserv. 45: 221-236.

Beck, H.H. 1942. Status of upland plover in Lancaster County, Pa. $A u k$ 59: 108-109.

Beintema, A.J. 1988. Conservation of grassland bird communities in the Netherlands. p.105 in P.D Goriup (ed.). Ecology and conservation of grassland birds, ICBP Tech. Pub. 7.

Best, L.B. 1986. Conservation tillage: ecological traps for nesting birds? Wildl. Soc. Bull. 14: 308-317.

R.C. Whitmore and G.M. Booth. 1990. Use of cornfields by birds during the breeding season: the importance of edge habitat. Am. Midl. Nat. 123: 84-99.

Birkenholz, D.E. 1973. Habitat relationships of grassland birds at Goose Lake Prairie Nature Preserve. p. 63 in L.C. Hulbert, (ed.). Proc. Third Midwest Prairie Conf., Kans. State Univ., Manhattan.

Bohlen, H.D. 1989. Birds of Illinois. Indiana University Press, Bloomington, Indiana. 
Bollinger, E.K. 1991. Conservation of grassland birds in agricultural areas. p. 279 in D.J. Decker, M.E. Krashy, G.R. Goff, C.R. Smith and D.W. Gross, (eds.). Challenges in the conservation of biological resources: a practitioners guide. Westview Press, Boulder, Co. P.B. Bollinger and T.A. Gavin. 1990. Effects of haycropping on Eastern populations of the bobolink. Wildl. Soc. Bull.18: 142-150.

Bowles, M.L., K. Kerr, R.H. Thom and D.E. Birkenholz. 1980. Threatened, endangered and extirpated birds of Illinois prairies. Ill. Aud. Bull. 193: $2-11$.

Bryan, G.G. and L.B. Best. 1991. Bird abundance and species richness in grassed waterways in Iowa rowcrop fields. Am. Mid. Nat. 126: 90-102. and — 1994. Avian nest density and success in grassed waterways in Iowa rowcrop fields. Wildl. Soc. Bull. 22: 583-592.

Bucher, E.H. and M. Nores. 1988. Present status of birds in steppes and savannahs of Northern and Central Argentina. p.71 in P.D. Goriup (ed.). Ecology and conservation of grassland birds, ICBP Tech Publ. 7. Buhnerkempe, J.E. 1979. Habitat utilization and partitioning within a community of nesting grassland birds. M.S. thesis, Eastern Illinois University, Charleston, IL. 58 p. and R.L. Westemeier. 1988. Breeding biology and habitat of upland sandpipers on prairie-chicken sanctuaries in Illinois. Trans. Ill. Acad. Sci. 81: 153-162.

Burger, L.D., L.W. Burger and J. Faaborg. 1994. Effects of prairie fragmentation on predation on artificial nests. J. Wildl. Manage. 58: 249-254. 
Burnham, K.P., D.R. Anderson and J.L. Laake. 1980. Estimation of density from line transect sampling of biological populations. Wildl. Monogr. No. 72.

Buss, I.O. and A.S. Hawkins. 1939. The upland plover at Faville Grove, Wis. Wilson Bull. 51: 202-219.

Camp, M. and L.B. Best. 1994. Nest density and nesting success of birds in roadsides adjacent to rowcrop fields. Am. Mid. Nat. 131:347-358.

Cavalcanti, R.B. 1988. Conservation of birds in the cerrado of Central Brazil. p. 59 in P.D Goriup (ed.). Ecology and conservation of grassland birds, ICBP Tech. Publ. 7.

Crossman, T.I. 1989. Habitat use by grasshopper and savannah sparrows at Bradley International Airport and management recommendations. M.S. Thesis. University of Connecticut. (unpublished manuscript).

Delany, M.F., H.M. Stevenson and R. McCracken. 1985. Distribution, abundance, and habitat of the Florida grasshopper sparrow. J. Wildl. Manage. 49: 626-631.

de Juana, E., T. Santos, F. Suarez and J.L. Tellaria. 1988. Status and conservation of steppe birds and their habitats in Spain. p. 113 in P.D. Goriup (ed.). Ecology and conservation of grassland birds, ICBP Tech. Publ. 7.

Emlen, J.T. 1971. Population densities of birds derived from transect counts. A uk 88: 323-342. 1977. Estimating breeding season bird densities from transect counts. Auk 94: 455-468.

Frawley, B.J. and L.B. Best. 1991. Effects of mowing on breeding bird abundance and species composition in alfalfa fields. Wildl. Soc. Bull. 
19: $135-142$.

Goriup, P.D. (ed.). 1988. Ecology and conservation of grassland birds. ICBP Tech. Publ. 7. Cambridge, U.K.

Graber, R.R. and J.W. Graber. 1963. A complete study of bird populations in Illinois. Ill. Nat. His. Surv. Bull. 28: 377-528.

Graul, W.D. 1980. Grassland management practices and bird communities. p. 38 in Degraff, R.M. and N.G. Tilghman (eds.). Management of western forests and grasslands for non-game birds. USDA Forest Serv. Gen. Tech. Rept. INT -86.

Henriksen, K. 1991. Breeding performance of ringed plovers on filled up areas in Arhus Harbor, Eastern Jutland (Denmark). Dansk. Ornithologisk Forenings Tidsskrift. 85: 63-66.

Herkert, J.R. 1991. Prairie birds of Illinois: population response to two centuries of habitat change. Ill. Nat. His. Bull.34: 393-399. (ed) 1992. Endangered and threatened species of Illinois: status and distribution, part 2 - animals. Illinois Endangered Species Protection Board. Springfield, IL. 1994a. The effects of habitat fragmentation on Midwestern grassland bird communities. Ecol. Appl. 4: 461-471. 1994b. Status and habitat selection of the Henslow's sparrow in Illinois. Wilson Bull. 106: 35-45.

Higgins, K.F., L.M. Kirsch and I.J. Ball. 1969. A cable-chain device for locating duck nests. J. Wildl. Manage. 33: 1009-1011.

Howe, R.W., G.J. Davis and V. Mosca. 1991. The demographic significance of 'sink' populations. Bio. Conserv. 57: 239-255.

Hurley, R.J. and E.C. Franks. 1976. Changes in the breeding ranges of two 
grassland birds. $A$ u $k$ 93: 108-115.

Illinois Department of Transportation: Division of Aeronautics. 1985.

Aviation safety rules. Springfield, IL. 52 pp.

Jarvinen, O. and R.A. Vaisanen. 1975. Estimate relative densities of breeding birds by the line transect method. Oikos 26: 316-322.

Johnson, R.G. and S.A. Temple. 1990. Nest predation and brood parasitism of tallgrass prairie birds. J. Wildl. Manage. 54: 106-111.

Kirsch, L.M, H.F. Duebbert and A.D. Kruse. 1978. Grazing and haying effects on habitats of upland nesting birds. Trans. N.A. Wildl. Nat. Res. Conf. 43: 486-497.

Knapton, R.W. 1988. Nesting success is higher for polygynously mated females than for monogamously mated females in the eastern meadowlark. Auk 105: 325-329.

Knopf, F.L. 1988. Conservation of steppe birds in North America. p. 71 in P.D. Goriup (ed.). Ecology and conservation of grassland birds, ICBP Tech. Publ. 7.

Laake, J.L., S.T. Buckland, D.R. Anderson and K.P. Burnham. 1994.

DISTANCE Users Guide V 2.1. Colorado Cooperative Fish and

Wildlife Research Unit, Colorado State University, Fort Collins, Co. 84 pp.

Mankin, P.C. and R.E. Warner. 1992. Vulnerability of ground nests to predation on an agricultural habitat island in East-central Illinois. Am. Mid. Nat. 128: 281-291.

Mayfield, H.F. 1961. Nesting success calculated from exposure. Wilson Bull. 73: 255-261.

1975. Suggestions for calculating nest success. Wilson Bull.87: $456-466$. 
McNicholl, M.K. 1988. Ecological and human influences on Canadian populations of grassland birds. p. 1 in P.D. Goriup (ed.). Ecology and conservation of grassland birds, ICBP Tech Pub. 7.

Osborne, D.R. and A.T. Peterson. 1984. Decline of the upland sandpiper (Bartramia longicauda) in Ohio: an endangered species. Ohio J. Sci. 84: 8-10.

Pulliam, R.H. 1988. Sources, sinks and population regulation. Am. Nat. 112: 652-661.

Rahmani, A. 1988. Grassland birds of the Indian subcontinent: a review. p. 187 in P.D. Goriup (ed.). Ecology and conservation of grassland birds, ICBP Tech. Pub. 7.

Renken, R.B. and J.J. Dinsmore. 1987. Non-game bird communities on managed grasslands in North Dakota. Can. Field Nat. 101: 551-557.

Ricklefs, R.E. 1969. An analysis of nesting mortality in birds. Smithsonian Contrib. Zoo. No. 9.

Rodenhouse, N.L. and L.B. Best. 1983. Breeding ecology of vesper sparrows in corn and soybean fields. Am. Mid. Nat. 110: 265-275.

Roseberry, J.L. and W.D. Klimstra. 1970. The nesting ecology and reproductive performance of the Eastern Meadowlark. Wilson Bull. 82: 243-267.

Ryan, M.R. 1986. Non-game management in grassland and agricultural ecosystems. in J.B. Hale, L.B. Best and R.L. Clawson (eds.). Management of non-game wildlife in the Midwest: a developing art.

Senner, S.E. 1994. Conservation of grassland birds. C.F.O. Journal 28: 99100.

Skinner, R.M. 1975. Grassland use patterns and prairie bird populations in 
Missouri. p. 171 in M.K. Wali (ed.). Prairie: a multiple view. North Dakota Press, Grand Forks.

Sokal, R.R. and F.J. Rohlf. 1981. Biometry, 3rd edition. W.H. Freeman and Company. 887p.p.

Sullivan, K.A. 1989. Predation and starvation: age-specific mortality in juvenile juncos. J. Anim. Eco. 58: 275-286.

Vance, D.R. 1976. Changes in land use and wildlife populations in Southeastern Illinois. Wildl. Soc. Bull.4:11-15.

Van Horne, B. 1983. Density as a misleading indicator of habitat quality. J. Wildl. Manage. 47: 893-901.

Vickery, P.D., M.L. Hunter and J.V. Wells. 1992a. Is density an indicator of breeding success? Auk 109: 706-710. and 1992b. Evidence of incidental nest predation and its effects on nests of threatened grassland birds. Oikos 63: 281-288. and S.M. Melvin. 1994. Effects of habitat area on the distribution of grassland birds in Maine. Conserv. Bio. 8: 1087-1097. Warner, R.E. 1992. Nest ecology of grassland passerines on road right-of-ways in Central Illinois. Bio. Conserv. 59: 1-7.

1994. Agricultural land use and grassland habitat in Illinois: future shock for Midwestern birds. Conserv. Bio. 8: 147-156.

Westemeier, R. and J. Buhnerkempe. 1983. Responses of nesting wildlife to prairie grass management on a prairie chicken sanctuary in Illinois. Proc. N.A. Prairie Conf. 8: 39-46.

Whitmore, R.C. 1979. Short-term change in vegetation structure and its effect on grasshopper sparrows in West Virginia. Auk 96: 621-625. 


\section{Structural characteristics of grasshopper sparrow}

habitat. J. Wildl. Manage. 45: 811-814.

Wiens, J.A. 1974. Climatic instability and the "ecological saturation" of bird communities in North American grasslands. Condor 76: 385-400.

Wray, T., K.A. Strait and R.C. Whitmore. 1982. Reproductive success of grassland sparrows on a reclaimed surface mine in West Virginia. A uk 99: 157-164. 


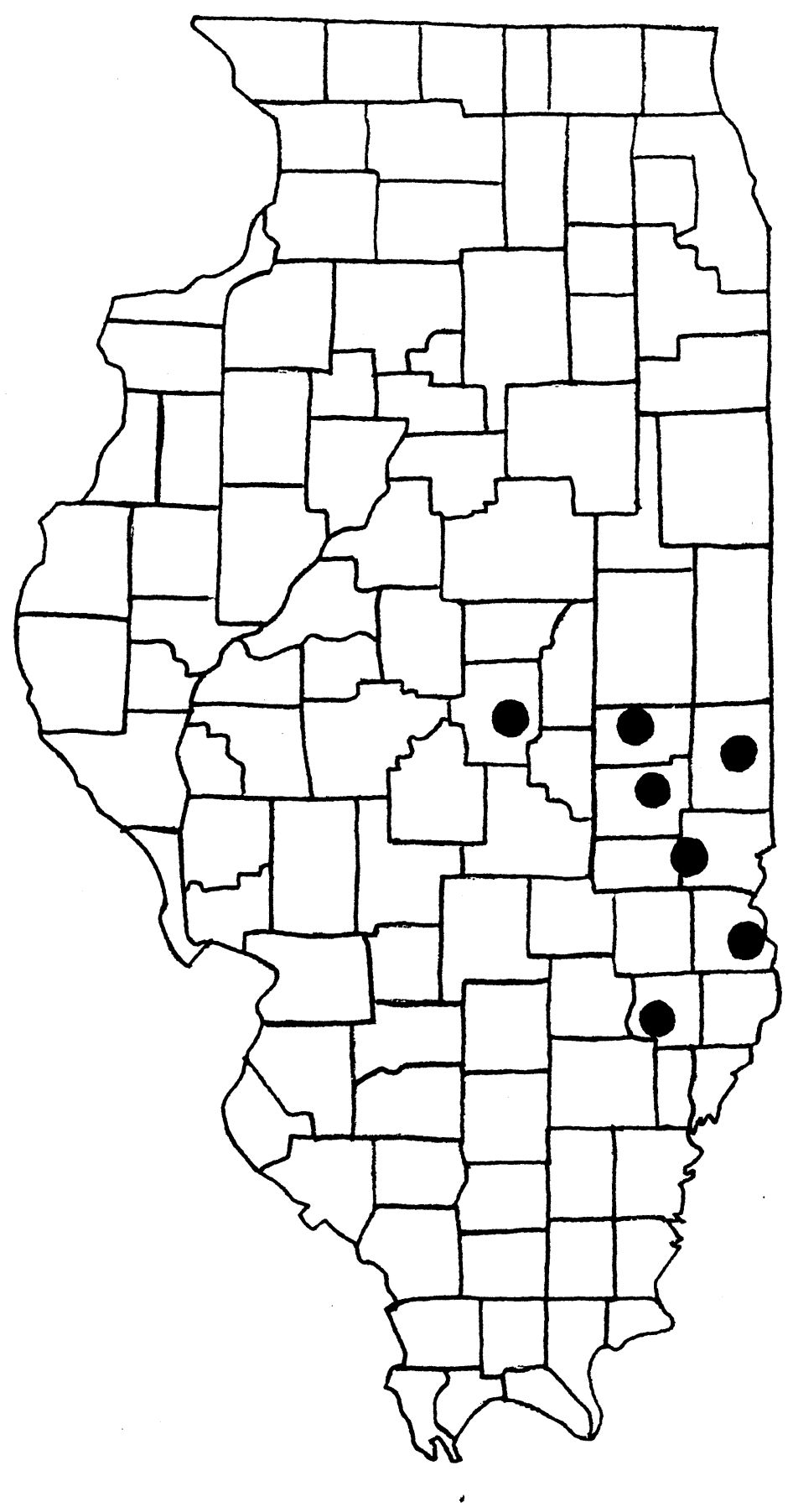

FIGURE 1: A map of Illinois showing the counties of the seven airports studied. 
Table 1: The number of nests, the percent of the total nests found, and the nest success for the six species found nesting on airport grasslands.

\begin{tabular}{lccl} 
Eastern Meadowlark & 105 & 71.4 & $0.14^{*}$ \\
Grasshopper Sparrow & 12 & 8.2 & 0.41 \\
Savannah Sparrow & 12 & 8.2 & 0.23 \\
Red-winged Blackbird & 11 & 7.5 & 0.06 \\
Song Sparrow & 4 & 2.7 & 0.44 \\
Horned Lark & 3 & 2.0 & 1.00 \\
\hline Totals & 147 & 100 & 0.14 \\
* only 76 of the total nests were used to calculate success. &
\end{tabular}




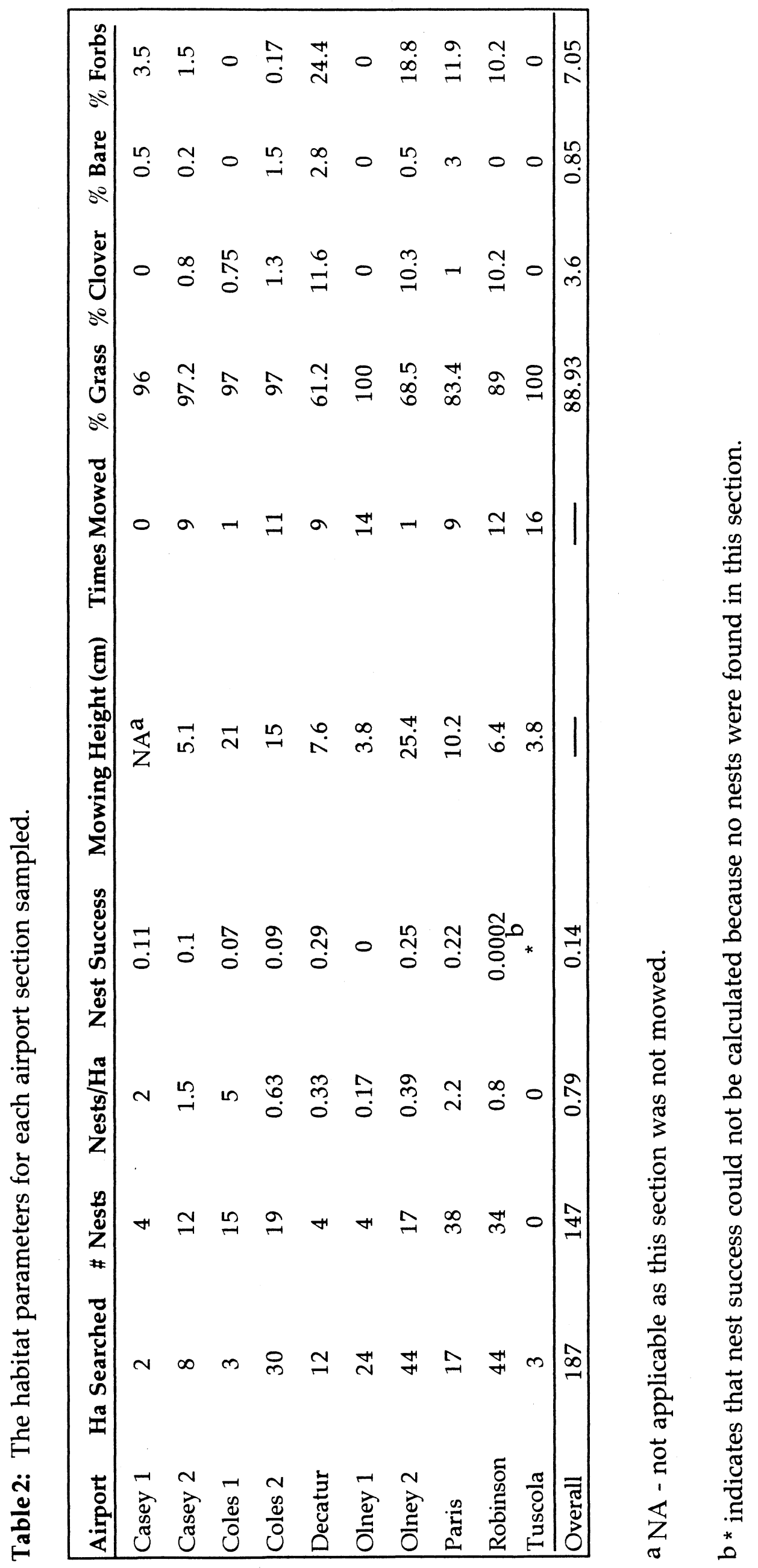


Table 3: Spearman Rank correlation coefficients between mowing height, mowing frequency, $\%$ grass cover, $\%$ clover cover, non-clover forb cover and airport area and nest density and nest success.

\begin{tabular}{lcc}
\hline & NEST DENSITY & NEST SUCCESS \\
\hline Mowing height & $0.510^{*}$ & 0.429 \\
Mowing frequency & $-0.659^{* *}$ & $-0.570^{*}$ \\
$\%$ Grass cover & -0.226 & $-0.778^{* * *}$ \\
$\%$ Clover cover & -0.031 & $0.544^{*}$ \\
$\%$ Other forbs & 0.080 & $0.820^{* * *}$ \\
Airport area & -0.250 & -0.134 \\
\hline \multicolumn{3}{l}{}
\end{tabular}




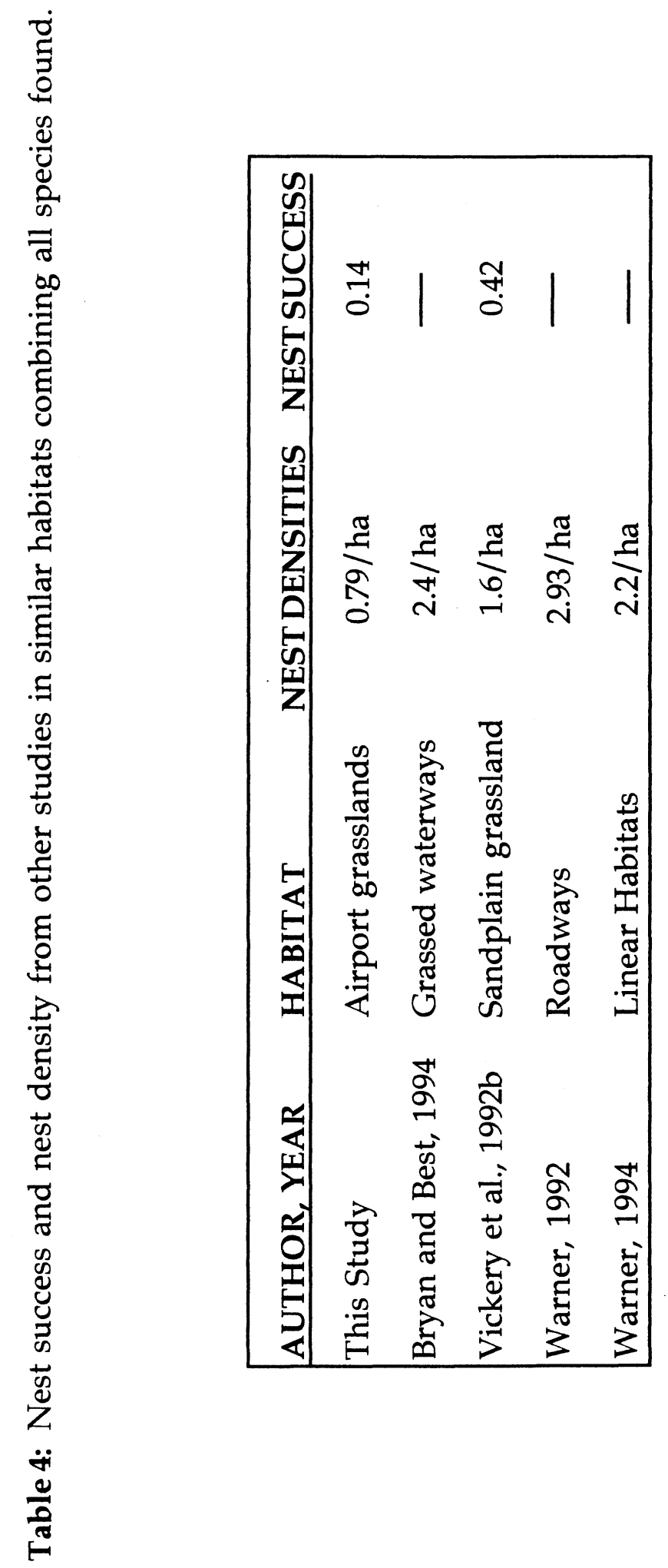

n 


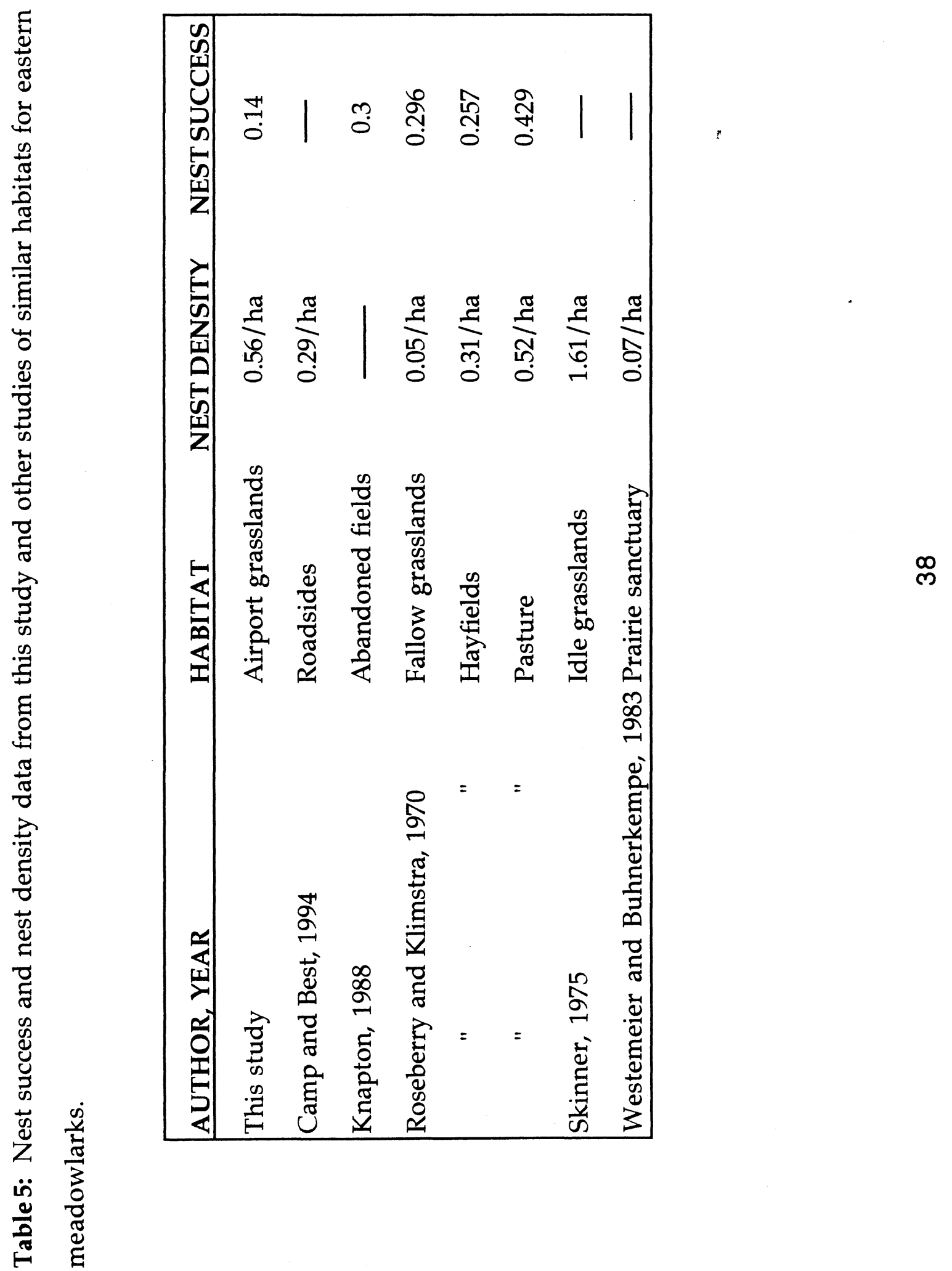


呬

ฮั

कृ

ช్య

हี

흐

छ

苟 $\frac{0}{3} \frac{0}{0}$

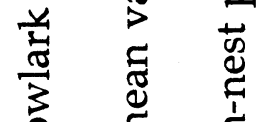

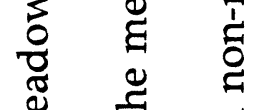

芩

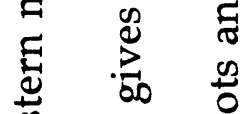

过

$+$

$\pi$

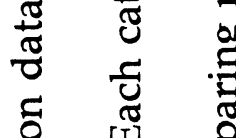

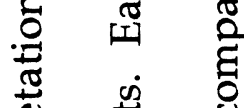

क્木

$\stackrel{\infty}{>}$

进

प

:

है छै

छ్ర

$4 \quad \frac{\infty}{4}$

$\ddot{0} 3$

范

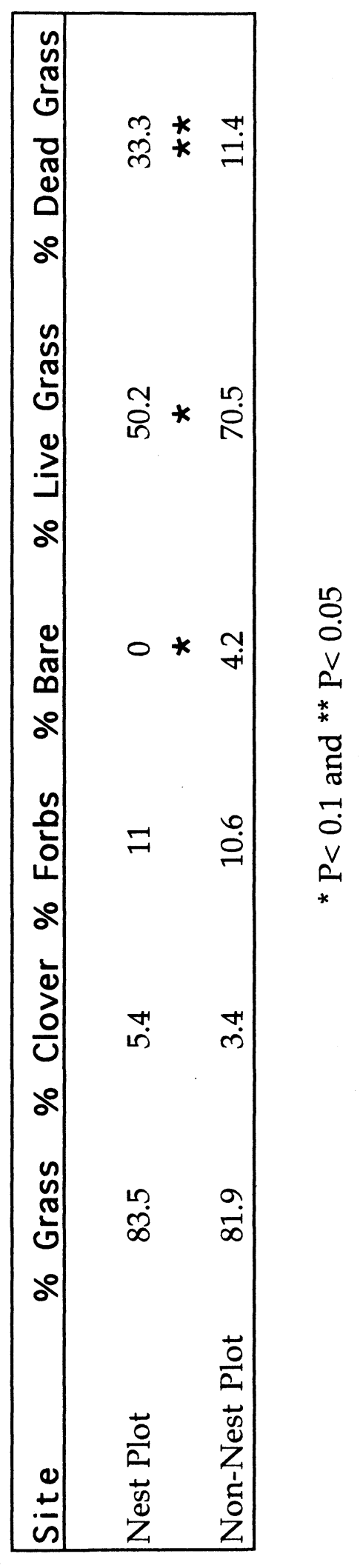

m 


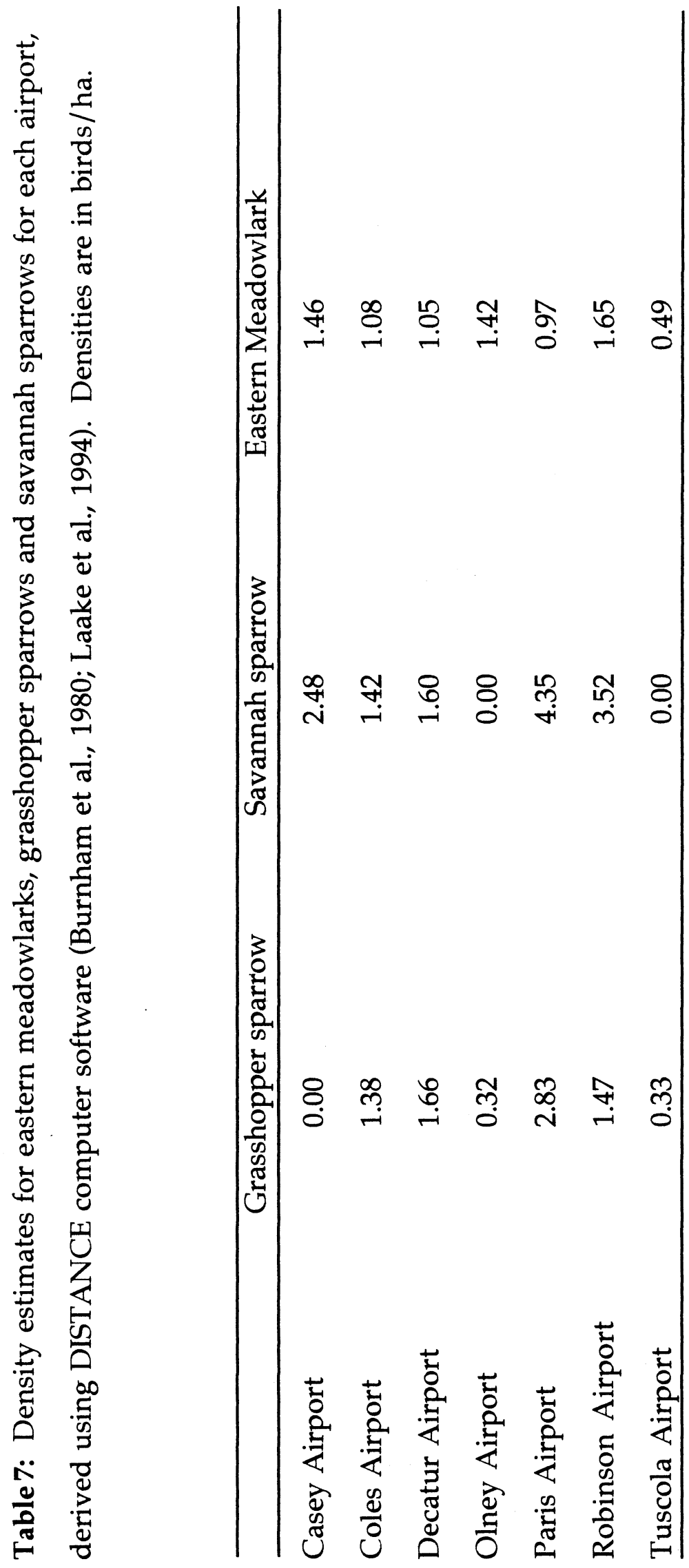

\& 
APPENDIX I : A list of all species observed on airport grasslands during the time of 10 April and 15 August, 1994.

American Crow - Corvus brachyrhynchos

American Robin - Turdus migratorius

American Woodcock - Philohela minor

Bobolink - Dolichonyx oryzivorus

Brown -headed Cowbird - Molothrus ater

Common Flicker - Colaptes auratus

Common Grackle - Quiscalus quiscula

Dickcissel - Spiza americana

Eastern Meadowlark - Sternella magna

European Starling - Sturnus vulgaris

Grasshopper Sparrow - Ammodramus savannarum

Greater Yellowlegs - Tringa melanoleuca

Horned lark - Eremophila alpestris

House Sparrow - Passer domesticus

Killdeer - Charadrius vociferus

Lesser Golden Plover - Pluvialis dominica

Mourning Dove - Zenaida macroura

Northern Bobwhite - Colinus virginianus

Pectoral Sandpiper - Calidris melanotos

"Peep Sandpipers - Calidris spp.

Red-tailed Hawk - Buteo jamaicensis

Red-winged Blackbird - Agelaius phoeniceus

Savannah Sparrow - Passerculus sandwichensis

Semipalmated Plover - Charadrius semipalmatus

Solitary Sandpiper - Tringa solitaria

Song Sparrow - Melospiza melodia

Vesper Sparrow - Pooectes gramineus

Upland Sandpiper - Bartramia longicauda 
APPENDIXII : A listing of the Endangered and threatened prairie bird species of Illinois. (Bowles et al., 1980; Herkert, 1991, 1992).

ENDANGERED

American bittern

Yellow Rail

Black Rail

Bachman's sparrow

Greater prairie chicken

Swainson's hawk

Short-eared owl

Northern harrier

Upland sandpiper

Sandhill crane

\section{THREATENED}

Loggerhead shrike

Henslow's sparrow

Brewer's blackbird 